\title{
Management Practices for Phosphorus and Sediment Reduction in the Salton Sea Watershed
}

\author{
Khaled M. Bali and Isabel Escabosa
}

\begin{abstract}
Nutrients, sediment and silt in drainage waters have been identified as the leading cause for water quality impairments in rivers and waterbodies in California. Approximately one-third of applied irrigation water leaves irrigated field as surface runoff and subsurface drainage.

In this project, we implemented seven standard and improved irrigation and fertigation management practices on a commercial alfalfa field to reduce the load and concentration of phosphorus and sediment in drainage waters. Reducing the amount of surface runoff after the application of $P$ fertilizer is a key factor in reducing the load of $P$ in drainage waters. The loads of $P$ in runoff waters were reduced by as much as $75 \%$ compared to normal irrigation and fertigation practices. Water-run application of $P$ increased the concentration and load of $P$ in runoff water by almost $100 \%$ compare to broadcast $P$ applications. Avoiding water-run applications can reduce the load of $P$ in runoff water by more than $50 \%$.
\end{abstract}

Index Terms-Irrigation management, phosphorus, sediments, water quality.

\section{INTRODUCTION}

In California and elsewhere, how much of a pollutant a waterbody can tolerate on a daily basis is determined by setting a Total Maximum Daily Load (TMDL). A TMDL for agricultural drainage is defined as the load allocations for non-point source of pollution and natural background pollution, plus a margin of safety such that the capacity of the waterbody to assimilate pollutant loadings without violating water quality standards is not exceeded. A TMDL can be expressed in terms of either mass per time, toxicity, concentration, a specific chemical or other appropriate measures.

To comply with TMDLs and mitigate the impacts of agriculture drainage waters on other uses, irrigators and farm managers have to be more attentive to the quality of the water applied and the quality of drainage waters leaving their fields, as they must adjust their irrigation practices to ensure compliance with the regulatory standards. The presence of suspended sediment, phosphorus $(P)$ and other contaminants adsorbed on suspended sediment in waterways has multiple negative impacts on water quality and may cause environmental problems [1]. The 1998 National Water Quality Inventory ranks suspended solids and sediment as the leading cause for water quality impairment of rivers and

Manuscript received August 31, 2013; revised November 1, 2013.

Khaled M. Bali is with University of California Cooperative Extension in Imperial County- University of California Desert Research and Extension Center, Holtville, California (e-mail: kmbali@ucdavis.edu).

Isabel Escabosa is with University of Baja California, Mexicali, Mexico (e-mail: isabel.escobosa@uabc.edu.mx). lakes in the United States [2].

Alfalfa is the principal crop in the Imperial Valley in southern California [3]. Approximately one billion cubic meter of water are used every year to irrigate 52,000 hectares of alfalfa. Approximately 10 million $\mathrm{kg}$ of phosphorus may be used annually to fertilize alfalfa in the Imperial Valley. Approximately $30 \%$ of applied drainage water in the Salton Sea watershed in southern California ends up as drainage water. Reducing the load and/or the concentration of suspended sediment in runoff has numerous benefits including reducing the amount of water applied and the load of other regulated contaminants such as pesticides and phosphorus that are attached to eroded soil particles.

The Salton Sea continues to exist because of the drainage water from agriculture in Imperial and Coachella Valleys as well as flow of agricultural drainage and untreated and partially treated sewage from the Mexicali Valley. As the largest inland body of water in California, the Salton Sea provides significant habitat for fish and wildlife. Rising salinity, sediment, nutrients, and other pollutions threaten these habitats. Excessive loads of nutrients (mainly phosphorus and nitrogen) in Imperial Valley drains and rivers have contributed to the eutrophic conditions in the Salton Sea that impair the designated beneficial uses of the Sea. In this project, we summarize our experience in using irrigation and fertigation management practices to reduce the load of phosphorus in runoff water from irrigated fields in the Imperial Valley.

\section{MATERIALS AND METHODS}

\section{A. Phosphorous Load in Runoff Waters}

Surface irrigation, by mainly of furrows or border checks, is the primary method for irrigation in the Imperial Valley, and is used on more than $90 \%$ of the cropped area. Drip irrigation is used on less than $5 \%$ of the cropped area and mostly on vegetable crops. Sprinkler irrigation is mostly used to germinate some crops, but growers switch to surface methods once the crop is established.

The average concentration of suspended sediment in Imperial Valley drains and rivers is approximately 350-400 $\mathrm{mg} / \mathrm{L}$. Based on the average agricultural drainage discharge of approximately 6,000 cubic meter per hectare/year, this figure represents a net loss of approximately 2.25 ton of soil (in form of sediment) per hectare per year. The average sediment load to drains and rivers in the Valley is in excess of 450,000 tons per year. In addition to the loss of productive topsoil, sediment and eroded soil particles contain considerable amounts of $P$ attached to soil particles that 
eventually end up in the Salton Sea. The average concentration of soluble $P$ in drainage water is approximately $0.5-1.0 \mathrm{mg} / \mathrm{L}$ (eutrophication, a major problem in the Salton Sea, can occur at concentrations as low as $0.02 \mathrm{mg} / \mathrm{L}$ ). The average load of $\mathrm{P}$ in drainage water in form of $\mathrm{P}_{2} \mathrm{O}_{5}$ is approximately $6-11 \mathrm{~kg} / \mathrm{ha}$ per year, with an average annual load of approximately 1.14 million $\mathrm{kg}$ of $P$ that end up in the Salton Sea every year.

Approximately 10 million $\mathrm{kg}$ of phosphorus (in the form of phosphate; $\mathrm{P}_{2} \mathrm{O}_{5}$ ) are used annually to fertilize the alfalfa crop [6], and this amount accounts for almost $50 \%$ of the total phosphorus applied to crops in the Valley. Phosphorus is applied once or twice per year as water-run phosphorus or broadcasted during the growing season with subsequent yearly applications in the springtime, or applied at a higher rate prior to planting to meet alfalfa demand for the entire growing season (approximately 3-4 years). The estimated phosphorus load in surface runoff waters is approximately $10-15 \%$ of total applied phosphorus. Phosphorus may move directly to surface waters via sediment carried in the surface runoff, and via cracks in the soil to subsurface drains.

\section{B. Field Experiments}

A commercial alfalfa field in the Imperial Valley, California was selected to conduct the project. The field is approximately 32 hectares and it was planted with alfalfa in October 2004. Seven best management techniques (BMTs) for $\mathrm{P}$ load reduction were implemented during the second year and third year after of the project (first year normal practices, BMTs in 2nd and 3rd year). The field consisted of 13 standard borders approximately $61 \mathrm{~m}$ wide by approximately $366 \mathrm{~m}$ long. Flumes to measure water flow rates were installed at the head end and at the tail end of the field.

Hay samples were collected at 91 and $274 \mathrm{~m}$ along each border prior to each cutting. Alfalfa yields were determined from sample cuttings and from bales. The numbers of hay bales on each border were recorded and the weight and moisture of selected bales were measured. Hay yields were determined from bale and hay samples data. Runoff water samples from each land were collected and the concentration of $P$ and other water quality constituents (Table I) were determined.

TABLE I: ANALYTICAL INSTRUMENTS AND Flow RATE MEASUREMENT METHODS AND QuALITy AsSURANCE OBJECTIVES

\begin{tabular}{|c|c|c|c|c|c|c|}
\hline Parameter & Method & Units & Detection limit & Sensitivity & Precision & Accuracy \\
\hline Water delivered & Trapezoidal flume & Cfs & 0 to 25 & $0.5 \mathrm{cfs}$ & $\pm 4 \%$ & $\pm 10 \%$ \\
\hline Runoff water & Long-throated flume & Cfs & 0 to 9 & $0.2 \mathrm{cfs}$ & $\pm 5 \%$ & \pm 10 \\
\hline $\mathrm{PO}_{4}$ & $\begin{array}{c}\text { US-EPA } 365.2 \\
\text { (Acid Persulfate Digestion) }\end{array}$ & $\mathrm{Mg} / \mathrm{L}$ & $0-3.5$ & 0.01 & $\pm 5 \%$ & $\pm 5 \%$ \\
\hline Salinity & EC (Tanji, 1990) & $\mathrm{dS} / \mathrm{m}$ & $0-3.0$ & 0.05 & $\pm 2 \%$ & $\pm 5 \%$ \\
\hline $\mathrm{NO}_{3}$ & $\begin{array}{l}\text { Spectrum }{ }^{\mathrm{TM}} \text { (Cadmium } \\
\text { Reduction Method) }\end{array}$ & $\mathrm{Mg} / \mathrm{L}$ & $0-30.00$ & 0.01 & $\pm 5 \%$ & $\pm 10 \%$ \\
\hline $\begin{array}{c}\text { Turbidity/ standard } \\
\text { method }\end{array}$ & US-EPA 180.1 & NTU & $0-1000$ & 0.1 & $\pm 2 \%$ & $\pm 5 \%$ \\
\hline $\begin{array}{c}\text { Turbidity/ } \\
\text { OBS-3 Suspended solids } \\
\text { and turbidity monitor }\end{array}$ & D \& A Instrument Company & $\begin{array}{l}\text { FTU } \\
\mathrm{Mg} / \mathrm{L}\end{array}$ & $\begin{array}{c}0.02-2,000 \\
0.1-5,000 \\
\left(\mathrm{Mud}, \mathrm{D}_{50}=10 \mathrm{um}\right)\end{array}$ & & $\begin{array}{c}2.0 \% \\
\text { (nonlinearity) } \\
2.0 \% \\
\text { (nonlinearity }\end{array}$ & \\
\hline
\end{tabular}

The following $P$ agricultural BMTs were implemented on the field:

1) Irrigation water management- determining and controlling the rate, amount, and timing of irrigation water applied.

2) Runoff reduction- reducing the amount of surface runoff, using a runoff reduction method developed by UCCE [4], [5], in just a single irrigation per year when broadcast $P$ fertilizer is applied

3) Precision application rates/GIS utilization- applying precise amounts of $P$-fertilizer to the soil in specific parts of the fields according to the plant needs.

4) Proper fertilizer applications- selecting the proper time and method of fertilizer application (water-run $P$ or broadcast- $P$ applications) to reduce $P$ losses through runoff and soil erosion.

5) Improved water-run $P$ application practicesapplying $112 \mathrm{~kg} / \mathrm{ha}$ (equivalent $\mathrm{P}_{2} \mathrm{O}_{5}$ ) of water-run phosphorous in a single irrigation.

6) Reduced water-run $P$ application practicesapplying 75 pounds/acre of water-run phosphorous fertilizer (in the form of $\mathrm{P}_{2} \mathrm{O}_{5}$ ) to the first $75 \%$ of the border.

7) Filter strip- establishing a section of land in permanent vegetation, down slope of agricultural operations.

Water-run phosphorus or dry phosphorus was applied to selected lands according to the schedule (Fig. 1 - Fig. 3).

\section{Phosphorus Application Rates and Methods}

Dry $P$ fertilizer (11-52-0) at a rate of approximately 112 $\mathrm{kg} / \mathrm{ha}$ of $\mathrm{P}_{2} \mathrm{O}_{5}$ (or $215 \mathrm{~kg} / \mathrm{ha}$ of actual fertilizer) per acre was applied to 12 lands in October 2004 prior to alfalfa planting. Three times the standard rate was applied to land 2 . The first application practice $(215 \mathrm{~kg} / \mathrm{ha}$ of dry $P$ fertilizer) mentioned above is the normal practice in the Imperial Valley. Some growers prefer to apply three times the yearly standard rate prior to planting instead of applying $215 \mathrm{~kg} / \mathrm{ha}$ of actual fertilizer prior to planting then subsequent applications during the second and third years of the alfalfa growing period. A summary of the $P$ application rates and methods prior to alfalfa planting is presented in Fig. 1. Phosphorus fertilizer was applied again in 2006 (approximately one year after the first hay harvest in 2005) and in spring of 2007. The 
rates and methods of application in 2006 and 2007 are

summarized in Fig. 2 and Fig. 3 respectively.

\begin{tabular}{|c|c|c|c|c|c|c|c|c|c|c|c|c|c|}
\hline Date & L1 & L2 & L3 & L4 & L5 & L6 & L7 & L8 & L9 & L10 & L11 & L12 & $\begin{array}{l}\text { L13 } \\
\text { extra }\end{array}$ \\
\hline $\begin{array}{l}\text { March } \\
2006\end{array}$ & $\begin{array}{l}S \\
R R\end{array}$ & Zero & Zero & Zero & Zero & Zero & $S$ & $\begin{array}{l}S \\
R R\end{array}$ & $\begin{array}{l}S \\
R R\end{array}$ & $S$ & Zero & Zero & $S$ \\
\hline BMT & 2 & & & & & & 4 & 2 & 2 & 4 & & & 4 \\
\hline $\begin{array}{l}\text { April } \\
2006\end{array}$ & Zero & Zero & $\begin{array}{l}\text { WR } \\
100 \%\end{array}$ & $\begin{array}{l}\text { WR } \\
75 \%\end{array}$ & $\begin{array}{l}\text { WR } \\
75 \%\end{array}$ & $\begin{array}{l}\text { WR } \\
100 \%\end{array}$ & Zero & Zero & Zero & Zero & $\begin{array}{l}\text { WR } \\
100 \%\end{array}$ & $\begin{array}{l}\text { WR } \\
75 \%\end{array}$ & Zero \\
\hline BMT & & & 5 & 6 & 6 & 5 & & & & & 5 & $6,7(\mathrm{FS})$ & $7(\mathrm{FS})$ \\
\hline
\end{tabular}

S: Standard rate: $215 \mathrm{~kg} / \mathrm{ha}$ of 11-52-0 (broadcast), approximately $112 \mathrm{~kg} / \mathrm{ha}$ of $\mathrm{P}_{2} \mathrm{O}_{5}$

WR: Water run-P (phosphoric acid) approximately $112 \mathrm{~kg} / \mathrm{ha}$ of $\mathrm{P}_{2} \mathrm{O}_{5}$

$100 \%$ : Water run-P applied during the irrigation time

$75 \%$ : Water run-P applied during the first $75 \%$ of irrigation time

RR: Reduced runoff

FS: Filter strip in 2006/2007

Fig. 1. Phosphorus application rates and methods in 2004 prior to planting.

\begin{tabular}{|l|l|l|l|l|l|l|l|l|l|l|l|l|l|}
\hline Date & L1 & L2 & L3 & L4 & L5 & L6 & L7 & L8 & L9 & L10 & L11 & L12 & $\begin{array}{l}\text { L13 } \\
\text { extra }\end{array}$ \\
\hline $\begin{array}{l}\text { April } \\
2007\end{array}$ & S & Zero & Zero & Zero & Zero & Zero & S & S & S & S & Zero & Zero & S \\
BMT & 4 & & & & & & & & & & & & \\
\hline $\begin{array}{l}\text { April } \\
2007\end{array}$ & Zero & Zero & WR & WR & WR & WR & Zero & Zero & Zero & Zero & WR & WR & Zero \\
BMT & & & $100 \%$ & $75 \%$ & $75 \%$ & $100 \%$ & & & & & $100 \%$ & $75 \%$ \\
\hline $\begin{array}{l}\text { October } \\
2007\end{array}$ & PA & PA & PA & PA & PA & PA & PA & PA & PA & PA & PA & PA (FS) & 7 (FS) \\
BMT & 3 & 3 & 3 & 3 & 3 & 3 & 3 & 3 & 3 & 3 & 3 & 3 \\
\hline
\end{tabular}

S: Standard rate: $215 \mathrm{~kg} / \mathrm{ha}$ of 11-52-0 (broadcast), approximately $112 \mathrm{~kg} / \mathrm{ha}$ of $\mathrm{P}_{2} \mathrm{O}_{5}$

WR: Water run-P (phosphoric acid) approximately $112 \mathrm{~kg} / \mathrm{ha}$ of $\mathrm{P}_{2} \mathrm{O}_{5}$

$100 \%$ : Water run-P applied during the irrigation time

$75 \%$ : Water run-P applied during the first $75 \%$ of irrigation time

FS: Filter strip in 2006/2007

PA: Precision application based on plant needs (soil testing and/or alfalfa uptake load, approx. $112 \mathrm{~kg} / \mathrm{ha}$ of $\mathrm{P}_{2} \mathrm{O}_{5}$ per 8 tons of alfalfa)

Fig. 2. Phosphorus application rates and methods in 2006.

\begin{tabular}{|l|l|l|l|l|l|l|l|l|l|l|l|l|l|}
\hline & L1 & L2 & L3 & L4 & L5 & L6 & L7 & L8 & L9 & L10 & L11 & L12 & $\begin{array}{l}\text { L13 } \\
\text { extra }\end{array}$ \\
\hline BMT & $2,3,4$ & 3 & 3,5 & 3,6 & 3,6 & 3,5 & 3,4 & $2,3,4$ & $2,3,4$ & 3,4 & 3,5 & $3,6,7$ & $3,4,7$ \\
\hline$P$ rate & M1 & M2 & M3 & M3 & M3 & M3 & M1 & M1 & M1 & M1 & M3 & M3 & M1 \\
\hline $\begin{array}{l}\text { Total } P \\
\text { Applied } \\
\begin{array}{l}11-52-0 \\
\text { equivalent } \\
\text { (b/ac) }\end{array}\end{array}$ & 600 & 600 & 600 & 500 & 500 & 600 & 600 & 600 & 600 & 600 & 600 & 500 & 600 \\
\hline $\begin{array}{l}\text { Total yield } \\
\begin{array}{l}2006 \text { and } \\
\text { 2007 }\end{array}\end{array}$ & & & & & & & & & & & & & \\
\hline
\end{tabular}

Summary of total practices

M1: Standard practice (broadcast first, second, and third year)

M2: Standard practice (broadcast first year at 3 times the annual rate)

M3: Standard practice (broadcast first year, water run second and third year)

Fig. 3. Phosphorus application rates and methods in 2007.

\section{RESUlTS AND DisCUSSION}

\section{A. Suspended Solids Concentration-Turbidity $(C-T)$ Relationship in Runoff Water}

The concentrations of sediment $(C)$ in runoff water were determined from turbidity $(T)$ values using three $C-T$ functions determined earlier in a previous study [7]. Three possible $C$ - $T$ functions were tested by regression analysis (1) linear function, (2) threshold linear functions (i.e. two linear functions for data with $N T U<200$ and $N T U \geq 200$ ), and (3) power function. The regression results were compared with one another and the function with the best fit was selected.
For all turbidity measurements, the errors between the reading and the standard values were between $0.2 \%$ and $2.4 \%$ signifying that the turbidity values measured by the turbidity meter were reliable. The regression results based on the data and their corresponding relations are:

Linear function

$$
C=0.876 T+29.2
$$

Threshold linear functions

$$
\begin{array}{ll}
C=1.162 T+18.5 & N T U<200 \\
C=0.898 T+12.1 & N T U \geq 200
\end{array}
$$


Power function

$$
C=3.6 T^{0.8}
$$

Although the linear function fitted the data well for high turbidity values, it over predicted $C$ for $T$ values less than 30 $N T U$. The two threshold linear functions agreed with the data well at high turbidity values but still over predicted $C$ at low turbidity values. In addition, the two intercepts in the two types of linear functions indicated that as turbidity approached zero, $C$ was 29.2 and $18.5 \mathrm{mg} / \mathrm{L}$, respectively. This was contradicting to the value (i.e. zero) generated by pre-programmed formazin calibration. The power function fitted the data well at both low and high turbidity values. Validation of Eq. (3) using the data collected in previous experiments indicated that the power function represented the best relationship between $C$ and $T$. Therefore, we used Eq. (3) to calculate the concentration of sediment in runoff water.

\section{B. Sediment and Phosphorus Concentrations and Loads in Runoff Waters}

The average concentration of suspended sediment in runoff water for all irrigation and $\mathrm{P}$ application practices in 2006 was lower than $100 \mathrm{mg} / \mathrm{L}$ (Table II). That is well below the TMDL threshold rate of $200 \mathrm{mg} / \mathrm{L}$. This indicates that the irrigation or fertigation practices implemented here had little impact on water quality.

\begin{tabular}{|c|c|c|c|c|c|}
\hline \multirow[b]{2}{*}{$\begin{array}{c}\text { Irrigation number after } P \\
\text { application }\end{array}$} & \multirow[b]{2}{*}{ Irrigation date } & \multicolumn{4}{|c|}{$\mathrm{P}$ application type and irrigation practice } \\
\hline & & $\begin{array}{c}\text { Standard } P \text { rate } \\
\text { broadcast- } \\
\text { standard irrigation } \\
\text { (borders L7, L10, } \\
\text { L13) }\end{array}$ & $\begin{array}{l}\text { Standard } P \text { rate } \\
\text { broadcast- } \\
\text { reduced runoff } \\
\text { (borders } \mathrm{L} 1, \mathrm{~L} 8 \text {, } \\
\text { L9) }\end{array}$ & $\begin{array}{l}\text { Standard } P \text { rate } \\
\text { water-run- } \\
\text { standard } \\
\text { irrigation } \\
\text { (borders L3,L6, } \\
\text { L11) }\end{array}$ & $\begin{array}{c}75 \% \text { of } \\
\text { standard } P \\
\text { rate- } \\
\text { water-run- } \\
\text { standard } \\
\text { irrigation } \\
\text { (borders L4, } \\
\text { L5, L12) } \\
\end{array}$ \\
\hline Pre-application irrigation & $3 / 21-23 / 2006$ & 40 & 50 & 41 & 43 \\
\hline $1^{\text {st }}$ irrigation & $4 / 27 / 2006$ & 59 & 44 & 39 & 79 \\
\hline 2nd irrigation & $5 / 10 / 2006$ & 46 & 43 & 44 & 43 \\
\hline $3^{\text {rd }}$ irrigation & $5 / 29 / 2006$ & 69 & 52 & 47 & 44 \\
\hline $5^{\text {th }}$ irrigation & $6 / 26 / 2006$ & 64 & 88 & 58 & 63 \\
\hline $6^{\text {th }}$ irrigation & $7 / 11 / 2006$ & 25 & 32 & 39 & 39 \\
\hline
\end{tabular}

TABLE III: Average PHOSPHORUS ( $\mathrm{PO}_{4}$ ) CONCENTRATION IN RunOFF WATER (MG/L) IN 2006

\begin{tabular}{|c|c|c|c|c|c|}
\hline \multirow[b]{2}{*}{$\begin{array}{c}\text { Irrigation number after } P \\
\text { application }\end{array}$} & \multirow[b]{2}{*}{ Irrigation date } & \multicolumn{4}{|c|}{$\mathrm{P}$ application type and irrigation practice } \\
\hline & & $\begin{array}{c}\text { Standard } P \text { rate } \\
\text { broadcast- } \\
\text { standard irrigation } \\
\text { (borders L7, L10, } \\
\text { L13) }\end{array}$ & $\begin{array}{l}\text { Standard } P \text { rate } \\
\text { broadcast- } \\
\text { reduced runoff } \\
\text { (borders L1, L8, } \\
\text { L9) }\end{array}$ & $\begin{array}{l}\text { Standard } P \text { rate } \\
\text { water-run- } \\
\text { standard } \\
\text { irrigation } \\
\text { (borders L3,L6, } \\
\text { L11) }\end{array}$ & $\begin{array}{c}75 \% \text { of standard } \\
P \text { rate- } \\
\text { water-run- } \\
\text { standard } \\
\text { irrigation } \\
\text { (borders L4, L5, } \\
\text { L12) }\end{array}$ \\
\hline Pre-application irrigation & $3 / 21-23 / 2006$ & 3.99 & 3.76 & 1.77 & 1.63 \\
\hline $1^{\text {st }}$ irrigation & $4 / 27 / 2006$ & 117.93 & 77.41 & 192.30 & 218.44 \\
\hline $2^{\text {nd }}$ irrigation & $5 / 10 / 2006$ & 3.97 & 4.35 & 5.49 & 5.62 \\
\hline $3^{\text {rd }}$ irrigation & $5 / 29 / 2006$ & 2.32 & 3.85 & 2.68 & 2.94 \\
\hline $5^{\text {th }}$ irrigation & $6 / 26 / 2006$ & 1.32 & 4.49 & 2.79 & 3.22 \\
\hline $6^{\text {th }}$ irrigation & $7 / 11 / 2006$ & 0.71 & 1.51 & 1.42 & 1.24 \\
\hline Average $\left(1 \mathrm{st}-6^{\text {th }}\right)$ & & 25.25 & 18.32 & 40.94 & 46.29 \\
\hline
\end{tabular}

The average concentrations of $P$ for selected irrigation and fertigation practices in 2006 are shown in Table III. The concentration of $P$ in runoff water prior to $P$ application practices was in the range of 1.63 to $3.99 \mathrm{mg} / \mathrm{L}$. The concentration of $P$ in runoff water increased dramatically after all $P$ application practices. The concentration of $P$ in runoff water after dry $P$ broadcast applications reached 118 $\mathrm{mg} / \mathrm{L}$ (Table III). However, the concentration of $P$ in runoff water after the water-run applications was much higher than the concentration after the dry $P$ broadcast applications (in excess of $218 \mathrm{mg} / \mathrm{L})$. Applying $P$ during the first $75 \%$ of irrigation time had no impact on $P$ concentration in irrigation water. The average concentration of $P$ in runoff water during the first six irrigations after $P$ applications was the highest for the $75 \%$ water-run $P$ application practice $(46 \mathrm{mg} / \mathrm{L})$. The standard broadcast-reduced runoff practice had the lowest average concentration of $18 \mathrm{mg} / \mathrm{L}$. That is more than 50\%lower than the concentration of $P$ in the water-run $P$ application practices.

The average load of $P$ during the first six irrigations after $P$ applications is about $1 \mathrm{~kg} / \mathrm{ha}$ per irrigation in the standard broadcast-reduced runoff irrigation (Table IV). The load of $P$ 
in runoff water for this treatment was almost $75 \%$ lower than any other $P$ application or fertigation practice. Controlling the rate and the amount of applied water is the most effective way to reduce the concentration and load of $P$ in runoff waters.

In 2007, the average concentration of suspended sediment in runoff water for all irrigation and $P$ application practices was lower than $105 \mathrm{mg} / \mathrm{L}$ (Table V). This is well below the TMDL target of approximately $200 \mathrm{mg} / \mathrm{L}$. This indicates that the irrigation or fretigation practices implemented here had little impact on sediment concentration in runoff water.

The average concentrations of $P$ prior to the $P$ application in April and in nine irrigation events after the application are shown in Table VI. The concentration of $P$ in runoff water prior to $P$ application practices was in the range of 1.34 to $2.24 \mathrm{mg} / \mathrm{L}$. The concentration of $P$ in runoff water increased dramatically after all $P$ application practices. The concentration of $P$ in runoff water after dry $P$ broadcast applications reached $54 \mathrm{mg} / \mathrm{L}$. The concentration of $P$ in runoff water after the water-run applications was higher than the concentration after the dry $P$ broadcast applications (in excess of $110 \mathrm{mg} / \mathrm{L}$ ). Applying $P$ during the first $75 \%$ of irrigation time had little impact on $P$ concentration in irrigation water. The average concentration of $P$ in runoff water during the first six irrigations after $\mathrm{P}$ applications was the highest for both the $100 \%$ and $75 \%$ water-run $P$ application practices. The standard broadcast application practices had average concentrations in the range of 7-8 $\mathrm{mg} / \mathrm{L}$. That is almost 50\%lower than the water-run $P$ application practices. These levels of reductions are similar to the levels obtained in 2006.

The average load of $P$ per irrigation during the first nine irrigations after $P$ applications is less than $1.5 \mathrm{~kg} / \mathrm{ha}$ per irrigation in the standard broadcast applications (Table VII). The load of $P$ in runoff water for these treatments was almost $50 \%$ lower than any other water-run $P$ application or fertigation practices. Controlling the rate and the amount of applied water is the most effective way to reduce the concentration and load of $P$ in runoff waters.

TABLE IV: AVERAge PHOSPHORUS $\left(\mathrm{PO}_{4}\right)$ CONCENTRATION AND LOAD IN RUNOFF WATER DURING THE FIRST Six IRRIGATION AFTER $P$ APPLICATION IN 2006*

\begin{tabular}{|c|c|c|}
\hline$P$ application type and irrigation practice & $\begin{array}{c}\text { Average } P \text { concentration }(\mathrm{mg} / \mathrm{L}) \\
\text { per irrigation }\end{array}$ & $\begin{array}{c}\text { Average } P \text { load per irrigation } \\
(\mathrm{kg} / \mathrm{ha})\end{array}$ \\
\hline Standard $P$ rate broadcast- standard irrigation (borders L7, L10, L13) & 25.25 \\
\hline Standard $P$ rate broadcast- reduced runoff (borders L1, L8, L9) & 18.32 \\
\hline Standard $P$ rate water-run- standard irrigation (borders L3, L6, L11) & 40.94 & 1.04 \\
\hline $75 \%$ of standard $P$ rate- water-run- standard irrigation (borders L4, L5, L12) & 46.29 & 7.95 \\
\hline
\end{tabular}

*Based on average application depth of $11.4 \mathrm{~cm}$ (standard irrigation)and runoff rates of $17 \%$ and $5 \%$ for standard irrigation and reduced runoff practices, respectively.

TABLE V: AVERAGE SEDIMENT CONCENTRATION IN RUNOFF WATER (MG/L)

\begin{tabular}{|c|c|c|c|c|c|}
\hline \multirow[b]{2}{*}{$\begin{array}{c}\text { Irrigation number after } P \\
\text { application }\end{array}$} & \multirow[b]{2}{*}{ Irrigation date } & \multicolumn{4}{|c|}{$P$ application type and irrigation practice } \\
\hline & & $\begin{array}{c}\text { Standard } P \text { rate } \\
\text { broadcast- standard } \\
\text { irrigation (borders } \\
\text { L7, L10, L13) }\end{array}$ & $\begin{array}{l}\text { Standard } P \text { rate } \\
\text { broadcast- reduced } \\
\text { runoff in } 2006 \\
\text { (borders L1, L8, } \\
\text { L9) } \\
\end{array}$ & $\begin{array}{c}\text { Standard } P \text { rate } \\
\text { water-run- standard } \\
\text { irrigation (borders } \\
\text { L3,L6, L11) }\end{array}$ & $\begin{array}{c}75 \% \text { of standard } P \text { rate- } \\
\text { water-run- standard } \\
\text { irrigation (borders L4, } \\
\text { L5, L12) }\end{array}$ \\
\hline Pre-application irrigation & $4 / 8 / 07$ & 59 & 83 & 68 & 63 \\
\hline $1^{\text {st }}$ irrigation & $4 / 28 / 07$ & 73 & 58 & 77 & 83 \\
\hline $2^{\text {nd }}$ irrigation & $5 / 10 / 07$ & 51 & 41 & 56 & 65 \\
\hline $3^{\text {rd }}$ irrigation & $6 / 2 / 07$ & 54 & 58 & 68 & 68 \\
\hline $4^{\text {th }}$ irrigation & $6 / 11 / 07$ & 44 & 41 & 54 & 47 \\
\hline $5^{\text {th }}$ irrigation & $6 / 28 / 07$ & 86 & 105 & 58 & 39 \\
\hline $6^{\text {th }}$ irrigation & $7 / 13 / 07$ & 42 & 43 & 48 & 44 \\
\hline $7^{\text {th }}$ irrigation & $7 / 31 / 07$ & 58 & 54 & 54 & 81 \\
\hline $8^{\text {th }}$ irrigation & $8 / 20 / 07$ & 54 & 42 & 74 & 51 \\
\hline $9^{\text {th }}$ irrigation & $9 / 09 / 07$ & 44 & 55 & 40 & 37 \\
\hline
\end{tabular}

TABLE VI: AVERAGE PHOSPHORUS $\left(\mathrm{PO}_{4}\right)$ CONCENTRATION IN RUNOFF WATER (MG/L) IN 2007

\begin{tabular}{|c|c|c|c|c|c|}
\hline \multirow[b]{2}{*}{$\begin{array}{c}\text { Irrigation number after } P \\
\text { application }\end{array}$} & \multirow[b]{2}{*}{ Irrigation date } & \multicolumn{4}{|c|}{$P$ application type and irrigation practice } \\
\hline & & $\begin{array}{l}\text { Standard } P \text { rate } \\
\text { broadcast- } \\
\text { standard } \\
\text { irrigation } \\
\text { (borders L7, L10, } \\
\text { L13) }\end{array}$ & $\begin{array}{c}\text { Standard } P \text { rate } \\
\text { broadcast- reduced } \\
\text { runoff in } 2006 \\
\text { (borders } L 1, L 8, L 9 \text { ) }\end{array}$ & $\begin{array}{l}\text { Standard } P \text { rate } \\
\text { water-run- } \\
\text { standard } \\
\text { irrigation } \\
\text { (borders L3,L6, } \\
\text { L11) }\end{array}$ & $\begin{array}{c}75 \% \text { of standard } P \text { rate- } \\
\text { water-run- standard } \\
\text { irrigation (borders L4, } \\
\text { L5, L12) }\end{array}$ \\
\hline Pre-application irrigation & $4 / 8 / 07$ & 1.34 & 2.24 & 1.73 & 1.76 \\
\hline $1^{\text {st }}$ irrigation & $4 / 28 / 07$ & 54.22 & 47.35 & 113.25 & 109.5 \\
\hline $2^{\text {nd }}$ irrigation & $5 / 10 / 07$ & 3.42 & 4.99 & 6.43 & 3.54 \\
\hline $3^{\text {rd }}$ irrigation & $6 / 2 / 07$ & 2.30 & 2.14 & 4.63 & 2.81 \\
\hline $4^{\text {th }}$ irrigation & $6 / 11 / 07$ & 1.70 & 1.83 & 2.22 & 1.57 \\
\hline $5^{\text {th }}$ irrigation & $6 / 28 / 07$ & 1.69 & 2.52 & 2.19 & 1.09 \\
\hline $6^{\text {th }}$ irrigation & $7 / 13 / 07$ & 0.98 & 1.11 & 1.46 & 1.09 \\
\hline $7^{\text {th }}$ irrigation & $7 / 31 / 07$ & 1.63 & 1.19 & 1.24 & 1.55 \\
\hline $8^{\text {th }}$ irrigation & $8 / 20 / 07$ & 1.54 & 0.75 & 2.11 & 1.73 \\
\hline $9^{\text {th }}$ irrigation & $9 / 09 / 07$ & 0.76 & 1.05 & 1.00 & 0.83 \\
\hline Average $\left(1^{\text {st }}-5^{\text {th }}\right)$ & & 7.58 & 6.99 & 14.95 & 13.75 \\
\hline
\end{tabular}


TABLE VII: AVERAGE PHOSPHORUS $\left(\mathrm{PO}_{4}\right)$ CONCENTRATION AND LOAD IN RUNOFF WATER DURING THE FIRST NINE IRRIGATIONS AFTER $P$ APPLICATION IN $2007^{*}$

\begin{tabular}{|c|c|c|}
\hline$P$ application type and irrigation practice & $\begin{array}{c}\text { Average } P \\
\text { concentration }(\mathrm{mg} / \mathrm{L}) \\
\text { per irrigation }\end{array}$ & $\begin{array}{l}\text { Average } P \text { load per } \\
\text { irrigation } \\
\text { (kg/ha) }\end{array}$ \\
\hline Standard P rate broadcast- standard irrigation (borders L7, L10, L13) & 7.58 & 1.47 \\
\hline Standard P rate broadcast- reduced runoff in 2006 (borders L1, L8, L9) & 6.99 & 0.40 \\
\hline Standard P rate water-run- standard irrigation (borders L3,L6, L11) & 14.95 & 2.90 \\
\hline $75 \%$ of standard P rate- water-run- standard irrigation (borders L4, L5, L12) & 13.75 & 2.67 \\
\hline
\end{tabular}

TABLE VIII: Average ALFALfa Yield in TON/AC BASEd ON ALFALFA Hay SAMPLES COLLECTED AT 91 AND 274 M ALONG EACH LAND IN 2006 AND TotAL YIELD PER CUTTING BASED ON BALES

\begin{tabular}{|c|c|c|c|c|c|c|c|c|c|}
\hline & & & & & & & & \\
Land No. & $3 / 10 / 06$ & $4 / 21 / 06$ & $5 / 17 / 06$ & $6 / 13 / 06$ & $7 / 19 / 06$ & $8 / 28 / 06$ & $10 / 17 / 06$ & $12 / 1 / 06$ & Total 2006 \\
\hline 1 & 1.69 & 1.77 & 1.62 & 2.06 & 1.94 & 1.64 & 1.06 & 1.00 & 12.78 \\
\hline 2 & 1.91 & 1.92 & 2.19 & 2.68 & 1.83 & 1.34 & 0.91 & 0.86 & 13.64 \\
\hline 3 & 1.70 & 1.84 & 1.81 & 2.15 & 1.80 & 1.28 & 1.01 & 0.81 & 12.40 \\
\hline 4 & 1.79 & 1.47 & 2.51 & 2.20 & 2.04 & 1.20 & 0.88 & 0.96 & 13.04 \\
\hline 5 & 1.72 & 1.68 & 2.28 & 2.73 & 1.90 & 1.21 & 0.87 & 0.68 & 13.07 \\
\hline 6 & 2.04 & 1.91 & 1.87 & 2.89 & 2.63 & 1.58 & 0.94 & 0.95 & 14.81 \\
\hline 7 & 2.06 & 1.76 & 2.09 & 2.15 & 2.04 & 1.47 & 0.90 & 1.01 & 13.48 \\
\hline 8 & 1.65 & 2.14 & 2.28 & 1.66 & 1.89 & 1.05 & 1.01 & 1.20 & 12.87 \\
\hline 9 & 1.68 & 1.86 & 1.68 & 2.66 & 2.11 & 1.43 & 0.86 & 1.07 & 13.36 \\
\hline 10 & 2.16 & 2.04 & 1.95 & 2.33 & 1.91 & 1.39 & 1.15 & 1.11 & 14.03 \\
\hline 11 & 1.88 & 1.98 & 1.72 & 1.49 & 2.04 & 1.59 & 1.34 & 1.07 & 13.11 \\
\hline 12 & 2.12 & 1.74 & 1.96 & 2.79 & 1.82 & 1.16 & 0.97 & 1.16 & 13.73 \\
\hline 13 & 1.67 & 1.63 & 1.61 & 2.55 & 1.71 & 1.23 & 0.96 & 0.90 & 12.26 \\
\hline $\begin{array}{c}\text { Average (hay } \\
\text { samples) }\end{array}$ & 1.85 & 1.83 & 1.97 & 2.33 & 1.97 & 1.35 & 0.99 & 0.98 & 13.28 \\
\hline $\begin{array}{c}\text { Average } \\
\text { (bales) }\end{array}$ & 1.10 & 1.13 & 1.39 & 1.83 & 1.63 & 0.98 & 0.74 & 0.71 & 9.49 \\
\hline
\end{tabular}

* December 2006 cutting: insect damage

TABLE IX: AVERAGE Alfalfa YiELD IN TON/AC BASED ON ALFALFA HAY SAMPLES COLLECTED AT 91 AND 274 M ALONG EACH LAND IN 2007

\begin{tabular}{|c|c|c|c|c|c|c|c|c|}
\hline Land No. & $3 / 15 / 07$ & 4/18/07 & $5 / 21 / 07$ & $6 / 18 / 07$ & $7 / 23 / 07$ & $9 / 24 / 07$ & $12 / 12 / 07$ & Total 2007 \\
\hline 1 & 0.95 & 1.35 & 1.69 & 1.07 & 1.22 & 1.03 & 0.84 & 8.14 \\
\hline 2 & 0.81 & 1.15 & 1.41 & 0.97 & 0.99 & 0.95 & 0.90 & 7.17 \\
\hline 3 & 0.70 & 1.42 & 1.58 & 1.69 & 1.17 & 1.10 & 0.82 & 8.48 \\
\hline 4 & 1.10 & 0.99 & 1.68 & 1.16 & 1.63 & 1.53 & 1.03 & 9.11 \\
\hline 5 & 0.66 & 1.04 & 1.46 & 1.66 & 0.90 & 0.86 & 0.69 & 7.27 \\
\hline 6 & 0.93 & 1.06 & 1.68 & 1.42 & 1.45 & 1.21 & 0.77 & 8.51 \\
\hline 7 & 1.07 & 1.05 & 1.70 & 1.35 & 1.53 & 1.37 & 0.97 & 9.04 \\
\hline 8 & 0.88 & 1.26 & 1.39 & 1.76 & 1.44 & 1.49 & 0.81 & 9.03 \\
\hline 9 & 1.01 & 1.38 & 1.68 & 1.75 & 1.84 & 1.42 & 0.97 & 10.04 \\
\hline 10 & 1.02 & 1.31 & 1.28 & 1.37 & 1.52 & 1.60 & 0.67 & 8.77 \\
\hline 11 & 1.15 & 1.39 & 1.92 & 1.74 & 1.49 & 1.62 & 0.82 & 10.12 \\
\hline 12 & 0.99 & 1.72 & 1.53 & 1.23 & 1.53 & 1.17 & 1.01 & 9.16 \\
\hline 13 & 0.86 & 1.22 & 1.31 & 1.24 & 1.12 & 1.07 & 0.81 & 7.64 \\
\hline Average & 0.93 & 1.26 & 1.56 & 1.42 & 1.37 & 1.26 & 0.85 & 8.65 \\
\hline $\begin{array}{c}\text { Average } \\
\text { (bales) }\end{array}$ & 0.44 & 0.89 & 1.62 & 1.27 & 1.02 & 0.43 & 0.63 & 6.30 \\
\hline
\end{tabular}

March 2007 cutting: damage due to cold weather in January 2007.

* September 2007: cutting damage due to heat stress and insects. 
TABLE X: Average Alfalfa YiEld (TONS/AC PER CuTTING) IN TwO CUTTINGS BEFORE AND IN THREE CUTTINGS AFTER THE $P$ APPLICATION IN 2006

\begin{tabular}{|c|c|c|c|c|}
\hline & \multicolumn{4}{|c|}{$P$ application type and irrigation practice } \\
\hline & $\begin{array}{l}\text { Standard } P \\
\text { rate } \\
\text { broadcast- } \\
\text { standard } \\
\text { irrigation } \\
\text { (borders L7, } \\
\text { L10, L13) }\end{array}$ & $\begin{array}{l}\text { Standard } P \\
\text { rate } \\
\text { broadcast- } \\
\text { reduced } \\
\text { runoff } \\
\text { (borders } \\
\text { L1, L8, L9) }\end{array}$ & $\begin{array}{l}\text { Standard } P \\
\text { rate } \\
\text { water-run- } \\
\text { standard } \\
\text { irrigation } \\
\text { (borders } \\
\text { L3,L6, L11) }\end{array}$ & $\begin{array}{l}75 \% \text { of } \\
\text { standard } P \\
\text { rate- } \\
\text { water-run- } \\
\text { standard } \\
\text { irrigation } \\
\text { (borders L4, } \\
\text { L5, L12) }\end{array}$ \\
\hline $\begin{array}{l}\text { Before } P \\
\text { application }\end{array}$ & 1.89 & 1.80 & 1.89 & 1.75 \\
\hline $\begin{array}{l}\text { After } P \\
\text { application }\end{array}$ & 2.04 & 1.99 & 2.04 & 2.25 \\
\hline $\begin{array}{l}\text { Amount of } \\
P \text { applied } \\
11-52-0 \\
\text { equivalent }\end{array}$ & 200 & 200 & 200 & 150 \\
\hline
\end{tabular}

TABLE XI: AVERAGE Alfalfa YiEld (TONS/AC PER CUTTING) IN Two CUTTINGS BEFORE AND IN THREE CUTTINGS AFTER THE $P$ APPLICATION IN 2007

\begin{tabular}{|l|l|l|l|}
\hline & \multicolumn{3}{|c|}{$P$ application type and irrigation practice } \\
\hline & $\begin{array}{l}\text { Standard } P \text { rate } \\
\text { broadcast- } \\
\text { standard } \\
\text { irrigation } \\
\text { (borders L1, L7, } \\
\text { L8, L19,10, } \\
\text { L13) }\end{array}$ & $\begin{array}{l}\text { Standard } P \text { rate } \\
\text { water-run- } \\
\text { standard } \\
\text { irrigation } \\
\text { (borders L3,L6, } \\
\text { L11) }\end{array}$ & $\begin{array}{l}\text { 75\% of standard } P \\
\text { rate- water-run- } \\
\text { standard irrigation } \\
\text { (borders L4, L5, } \\
\text { L12) }\end{array}$ \\
\hline $\begin{array}{l}\text { Before } P \\
\text { application }\end{array}$ & 1.11 & 1.11 & 1.08 \\
\hline $\begin{array}{l}\text { After } P \\
\text { application }\end{array}$ & 1.46 & 1.57 & 1.42 \\
\hline $\begin{array}{l}\text { Amount of } P \\
\text { applied } \\
\begin{array}{l}11-52-0 \\
\text { equivalent }\end{array}\end{array}$ & 200 & & \\
\hline
\end{tabular}

\section{Alfalfa Yield}

Alfalfa yields based on hay samplers collected at 91 and $274 \mathrm{~m}$ along each border and the total number of bales are shown in Table VIII, Table IX, Table X, and Table XI.

The average alfalfa yield in 2006 for the entire field $(9.5$ tons based on bale weight) is within the normal expected yields in the Imperial Valley. None of the implemented $P$ application practices had any negative impact on yield. The average yield in 2007 was relatively lower compare to normal years due to unusual freeze damage to the entire field and many alfalfa fields in the Valley. The night time temperatures were below freezing for more than one week in January of 2007. The temperature damage reduced alfalfa yield by 0.65 tons as compared to the same period in 2006 . None of the $P$ implementation practices in 2007 had any negative impact on alfalfa yield.

\section{A Precision Application of P-Fertilizer to the Soil in Specific Parts of the Fields According to the Plant Needs}

Phosphorus is the most important nutrient needed for alfalfa production. Potassium $(K)$ and sulfur are also important but in many soils in the low desert areas of California, the amount of $\mathrm{K}$ in the soil and irrigation water is sufficient for alfalfa growth. Most nutrients for alfalfa production come from the soil and some from irrigation water. The most effective way to evaluate the nutrient requirements for $P$ in alfalfa is to measure the concentration of $P$ in the plant tissues and the soil (Table XII). But sometimes, such as prior to planting, it is not possible to use plant tissue analysis to evaluate the status of $P$ in the alfalfa. Soil testing could also be helpful prior to planting to evaluate the amount of $P$ needed for alfalfa growth.

Soil testing and plat tissue analysis are needed to determine the amount of $P$ required for the proper application of $P$ and other fertilizers. Soil testing is usually conducted prior to planting and approximately two to three years after planting. Plant tissue analysis could be done every year or more frequently if needed. Soil samples should be taken from the first foot or so of the soil profile if broadcast $P$ was used applied to the field. Deeper samples may be needed if water-run $P$ was applied to the field. However, most of water uptake and nutrient uptake in alfalfa in the low desert region occurs from the top two to three feet of the soil profile. In heavy cracking clay soils, some of water-run $P$ may move to depths below three feet and may not be available to the alfalfa roots. It is better to avoid applying water-run $P$ when the soil profile is dry and deep cracks are present. Therefore, fertilizer application practices must be taken into account when soil testing is needed. Most top dressed P is in the top six inches of the soil profile.

Phosphorus analysis should be conducted using the Olsen method (for soils in southern California). The method is applicable for the conditions in the desert region (high $\mathrm{pH}$ and calcium soils and low organic matter). The phosphorus concentration should be reported in ppm (parts per million) $P$. If other units are used (such as $\mathrm{PO}_{4}$ or $\mathrm{P}_{2} \mathrm{O}_{5}$ ), the values should be converted to ppm $P$ using one the following equations:

$$
\begin{aligned}
& \mathrm{PO}_{4}=3.07 \times P \\
& \mathrm{P}_{2} \mathrm{O}_{5}=2.29 \times P
\end{aligned}
$$

For alfalfa, the following guidelines have been developed for $P$ soil tests:

$P$ concentrations between 0 and 6 ppm of $P$, the amount of $P$ in the soil is: LOW

$P$ concentrations between 7 and $10 \mathrm{ppm}$ of $P$, the amount of $P$ in the soil is: MARGINAL

$P$ concentrations higher than $10 \mathrm{ppm}$ of $P$, the amount of $P$ in the soil is: ADEQUATE

TABLE XII: THE AMOUNT OF P FERTILIZER NEEDED PER YEAR BASED ON SOIL $P$ TESTS

\begin{tabular}{|c|c|}
\hline $\begin{array}{c}\text { Soil test level } \\
(\mathrm{ppm})\end{array}$ & $\begin{array}{c}\text { Amount of } \mathrm{P}_{2} \mathrm{O}_{5} \text { needed per ac per year } \\
\text { (based on } 8-10 \text { tons of alfalfa per year) }\end{array}$ \\
\hline $0-3$ & 200 \\
\hline $3-6$ & 150 \\
\hline $6-10$ & 100 \\
\hline $10-15$ & 50 \\
\hline Above 15 & 0 \\
\hline
\end{tabular}

Most irrigated soils in the Imperial Valley have soil $P$ in excess of 5-10 ppm, therefore, applications of $P$ in excess of $112-168 \mathrm{~kg} / \mathrm{ha}$ of $\mathrm{P}_{2} \mathrm{O}_{5}$ may not be needed. The removal rate of $\mathrm{P}$ by alfalfa is about $7 \mathrm{~kg}$ of $\mathrm{P}_{2} \mathrm{O}_{5}$ per ton of hay. In general, dry forms of $\mathrm{P}$ fertilizers for alfalfa such as $11-52-0$ or $0-45-0$ are as effective as liquid forms (10-34-0, phosphoric acid).

In this project, soil samples were collected in September 2007 from depths varying from surface to $60 \mathrm{~cm}$ below the surface from two locations along each land (91 m and 274). Four soil samples were collected from each location (surface 
to $15 \mathrm{~cm}, 15-30 \mathrm{~cm}, 30-45 \mathrm{~cm}$, and $45-60 \mathrm{~cm}$ ). The samples at depths of 6 and 12 inches were analysed for available $P$ using the standard sodium bicarbonate-extractable phosphate method. The average concentration of $P$ and $K$ in soil samples and plant samples are presented in Table XIII and Table XIV, respectively.

TABLE XIII: The AVERAge Concentration OF Phosphorus ( $P$ IN PPM) AND Potassium ( $K$ IN PPM) IN SOIL SAMPLes Collected IN SEPTEMBER 2007

\begin{tabular}{|c|c|c|c|c|c|c|}
\hline $\begin{array}{l}\text { Land } \\
\text { No. }\end{array}$ & $\begin{array}{c}P \text { ppm } \\
\text { Average of } 4 \\
\text { samples }(0-30 \mathrm{~cm}) \\
\text { Two depths at two } \\
\text { locations }\end{array}$ & $\begin{array}{c}P \text { ppm } \\
\text { Average of } 2 \\
\text { samples }(0-15 \mathrm{~cm}) \\
\text { One depth at two } \\
\text { locations }\end{array}$ & $\begin{array}{c}P \text { ppm } \\
\text { Average of } 2 \text { samples } \\
(15-30 \mathrm{~cm}) \\
\text { One depth at two } \\
\text { locations }\end{array}$ & $\begin{array}{c}K \text { ppm } \\
\text { Average of } 4 \\
\text { samples }(0-30 \mathrm{~cm}) \\
\text { Two depths at two } \\
\text { locations }\end{array}$ & $\begin{array}{c}K \text { ppm } \\
\text { Average of } 2 \\
\text { samples }(0-15 \mathrm{~cm}) \\
\text { One depth at two } \\
\text { locations }\end{array}$ & $\begin{array}{c}K \text { ppm } \\
\text { Average of } 2 \text { samples } \\
(15-30 \mathrm{~cm}) \\
\text { One depth at two } \\
\text { locations }\end{array}$ \\
\hline 1 & 5.5 & 5.8 & 5.1 & 148.0 & 145.5 & 150.5 \\
\hline 2 & 5.5 & 5.6 & 5.5 & 151.8 & 155.0 & 148.5 \\
\hline 3 & 6.5 & 7.0 & 5.9 & 163.8 & 172.0 & 155.5 \\
\hline 4 & 5.8 & 6.2 & 5.5 & 150.0 & 156.5 & 143.5 \\
\hline 5 & 9.0 & 8.2 & 9.8 & 142.5 & 148.5 & 136.5 \\
\hline 6 & 9.8 & 10.1 & 9.5 & 158.8 & 162.5 & 155.0 \\
\hline 7 & 11.7 & 11.1 & 12.3 & 174.0 & 172.5 & 175.5 \\
\hline 8 & 10.7 & 10.9 & 10.5 & 181.0 & 184.0 & 178.0 \\
\hline 9 & 6.2 & 6.4 & 6.1 & 173.8 & 175.5 & 172.0 \\
\hline 10 & 8.4 & 7.9 & 8.9 & 179.3 & 178.0 & 180.5 \\
\hline 11 & 7.9 & 7.4 & 8.4 & 150.3 & 152.0 & 148.5 \\
\hline 12 & 10.0 & 10.2 & 9.9 & 174.8 & 178.5 & 171.0 \\
\hline 13 & 13.4 & 13.6 & 13.1 & 166.8 & 169.0 & 164.5 \\
\hline Average & 8.5 & 8.5 & 8.5 & 162.7 & 165.3 & 160.0 \\
\hline
\end{tabular}

TABLE XIV: THE AVERAGE CONCENTRATION OF PHOSPHORUS ( $\mathrm{PO}_{4}-P$ IN PPM) AND POTASSIUM $(K$ IN $\%)$ IN PLANT SAMPLES COLLECTED IN NOVEMBER 2007

\begin{tabular}{|c|c|c|c|c|c|c|}
\hline Land No. & $\begin{array}{c}\text { PO4- } P \text { ppm } \\
\text { Average of } 2 \\
\text { samples }(91 \mathrm{~m} \text { and } \\
274 \mathrm{~m})\end{array}$ & $\begin{array}{c}\text { PO4-P ppm } \\
\text { at } 91 \mathrm{~m}\end{array}$ & $\begin{array}{c}\text { PO4- } P \text { ppm } \\
\text { at } 274 \mathrm{~m}\end{array}$ & $\begin{array}{c}K \% \\
\text { Average of } 2 \\
\text { samples }(91 \mathrm{~m} \\
\text { and } 274 \mathrm{~m})\end{array}$ & $\begin{array}{c}K \% \\
\text { at } 91 \mathrm{~m}\end{array}$ & $\begin{array}{c}K \% \\
\text { at } 274 \mathrm{~m}\end{array}$ \\
\hline 1 & 1285 & 1290 & 1280 & 1.29 & 0.93 & 1.64 \\
\hline 2 & 1255 & 1360 & 1150 & 1.26 & 0.83 & 1.69 \\
\hline 3 & 1150 & 1160 & 1140 & 1.52 & 1.13 & 1.90 \\
\hline 4 & 1055 & 1180 & 930 & 1.87 & 1.65 & 2.09 \\
\hline 5 & 1395 & 1160 & 1630 & 1.00 & 1.01 & 0.98 \\
\hline 6 & 1165 & 960 & 1370 & 1.55 & 1.57 & 1.53 \\
\hline 7 & 1240 & 1120 & 1360 & 1.50 & 1.40 & 1.59 \\
\hline 8 & 1280 & 1270 & 1290 & 1.84 & 1.94 & 1.73 \\
\hline 9 & 1105 & 1160 & 1050 & 1.72 & 2.00 & 1.43 \\
\hline 10 & 1230 & 1140 & 1320 & 1.91 & 1.79 & 2.02 \\
\hline 11 & 1185 & 1250 & 1120 & 1.56 & 1.55 & 1.56 \\
\hline 12 & 1315 & 1440 & 1190 & 2.11 & 2.34 & 1.87 \\
\hline 13 & 1235 & 1400 & 1070 & 1.48 & 1.28 & 1.68 \\
\hline AVERAGE & 1223 & 1222 & 1223 & 1.58 & 1.49 & 1.67 \\
\hline
\end{tabular}

TABLE XV: INTERPRETATION OF TEST RESUlts FOR ALFALFA PLANT TISSUE SAMPLES TAKEN AT ONE-TENTH BLOOM [7]

\begin{tabular}{|c|c|l|l|l|c|c|}
\hline \multicolumn{2}{|c|}{} & \multicolumn{3}{c|}{ Plant tissue value } \\
\hline Nutrient & Plant part & Unit & Deficient & Marginal & Adequate & High \\
\hline $\begin{array}{c}\text { Phosphorus } \\
\text { (PO4- } P \text { ) }\end{array}$ & Middle third, stems & ppm & $300-500$ & $500-800$ & $800-1,500$ & Over 1,500 \\
\hline Potassium & Middle third, stems & $\%$ & $0.40-0.65$ & $0.65-0.80$ & $0.80-1.50$ & $\begin{array}{c}\text { Over } \\
1.50\end{array}$ \\
\hline
\end{tabular}


The average concentration of $K$ in the soil profile is about $163 \mathrm{ppm}$ that is above the threshold limit of about $150 \mathrm{ppm}$ of $K$. Therefore, $K$ fertilization is not needed. The average concentration of $P$ in all locations was about $8.5 \mathrm{ppm}$; therefore, additional $P$ application may be needed next spring in areas where $P$ concentration is below $10 \mathrm{ppm}$. However, alfalfa tissue testing is needed to determine the exact application rates and to determine the $P$ status in the plant.

Using soil $P$ test for determining the amount of $P$ needed for alfalfa is usually recommended prior to planting. However, for established stands, tissue testing is the most accurate method of determining the nutrient needs of alfalfa. Alfalfa samples were collected from at least 30 plants near the soil sampling locations. The samples were tested for $P$ and $K$ using the methods recommended by [8].

Table XV shows the recommendations of [7] for interpreting alfalfa tissues, based on this table; none of the 13 lands need any $P$ or $K$. The average concentration of $\mathrm{P}$ in all lands and at all location was in excess 1,200 ppm. The average concentration of $K$ was $1.58 \%$ and that is in the high range according to Tables IV-XIV.

\section{CONCLUSIONS}

Irrigation management is a key factor in controlling the concentration and the load of $P$ discharged from irrigation fields in the Imperial Valley. Reducing the rate of surface runoff during and after $P$ application practices could reduce $P$ load into surface waters by as much as $75 \%$ as compared to standard irrigation practices. Water-run application of $P$ increased the concentration and load of $P$ in runoff water by almost double the load generated from dry application practices.

\section{ACKNOWLEDGMENT}

This project was funded by the California State Water Resources Control Board. We also greatly appreciate the technical and financial support provided by USBR-Lower Colorado Region, Yuma Area Office.

We greatly appreciate the help and support that we received from Mr. Roland Leimgruber and his field crew during the project.

\section{REFERENCES}

[1] R. J. D. Colley and D. G. Smith, "Turbidity, suspended sediment, and water clarity: a review," Journal of the American Water Resources Association, vol. 37, pp. 1085-1101, 2001.

[2] P. G. Gao, G. B. Pasternack, K. M. Bali, and W. W. Wallender, "Estimating suspended sediment concentration using turbidity in an irrigation-dominated southeastern California watershed," American Society of Civil Engineers, Journal of Irrig. \& Drain. Engr., vol. 134, issue 2, pp. 250-259, March/April 2008.

[3] B. R. Hanson, K. M. Bali, and B. L. Sanden. (2008). Irrigating alfalfa in arid region. Irrigated Alfalfa Management in Mediterranean and Desert Zones. in C. G. Summers and D. H. Putnam, Eds., Oakland: University of California Agriculture and Natural Resources. Publication 8293. [Online]. (7). Available: http://alfalfa.ucdavis.edu/irrigatedalfalfa/

[4] K. M. Bali, M. E. Grismer, and I. C. Tod, "Reduced-runoff irrigation of alfalfa in imperial valley, California," American Society of Civil Engineers, Journal of Irrig. \& Drain. Engr., vol. 127, no. 3, pp. 123-130, 2001.

[5] M. E. Grismer and K. M. Bali, "Reduced-runoff irrigation of sudan grass hay, imperial valley, California," American Society of Civil Engineers, Journal of Irrig. \& Drain. Engr., vol. 127, no. 5, pp. 319-323, 2001.

[6] K. M. Bali, O. Bachie, R. A. Gonzalez, J. H. Soto, D. Buenrostro, and E. T. Natwick. (2013). Guidelines to production costs and practices for Imperial County-Field crops. UCCE_Imperial County Circular 104-F. [Online]. Available: http://ceimperial.ucdavis.edu

[7] P. G. Gao, G. Pasternack, K. M. Bali, and W. W. Wallender, "Impact of agricultural practices on soil erosion at the field scale in the salton sea watershed," in Proc. the Third International Conference on Irrigation and Drainage. Water District Management and Governance. USCID, 2005, pp. 571-580.

[8] R. D. Meyer, D. B. Marcum, S. B. Orloff, and J. L. Schmierer, "Alfalfa Fertilization Strategies," in Irrigated Alfalfa Management in Mediterranean and Desert Zones, C. G Summers and D. H. Putnam, Eds., Okland: University of California Agriculture and Natural Resources Publication 8292, 2007, ch. 6.

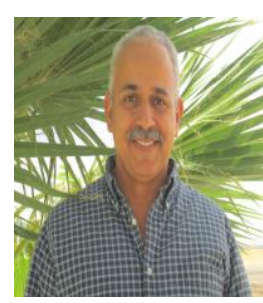

K. M. Bali is an irrigation/water management advisor and county director at the University of California Desert Research and Extension Center in Holtville, California. He holds a Ph.D. degree in 1992 in Soil Science (Soil Physics) and MS degree in 1987 in Water Science (Irrigation and Drainage) from the University of California at Davis. He holds a bachelor of science degree in 1984 in soils and irrigation from the University of Jordan, Amman. His main fields of scientific interest include water resources and management, water quality, irrigation systems, automation of surface irrigation, evapotranspiration, salinity, water quality, and reuse of wastewater for irrigation.

Dr. Bali is a member of many professional societies as American Geophysical Union and United States Committee on Irrigation and Drainage. $\mathrm{He}$ is a U.S. Fulbright scholar and served on a number of national and international scientific committees. 